\title{
Patronage, Citizenship, and the Stalled Emergence of the Modern State in Renaissance Florence
}

\author{
PAUL D. MCLEAN \\ Sociology, Rutgers University
}

Dearest honorable friend, Since I last wrote to you I have heard that you are among those who have been assigned to rearrange the tax burden, that is, these new taxes of the new distribution for our gonfalone. And therefore I pray of you most dearly, even though I think I need not, for you have me in mind already as recommended to yourself . . . truly that in the new distribution I am still [charged] one florin and a half. I believe you know more than enough of my feeble condition, and for this reason as much as I am able dearly I pray of you that in this matter you help me, and be the operator with your companions in such a mode as appears to you, that this half-florin assessment be lifted from me, so that I remain with the one florin, to pay a perdere [at a reduced rate, with loss of claim for reimbursement]. Concerning this I write no more, except that I have such hope

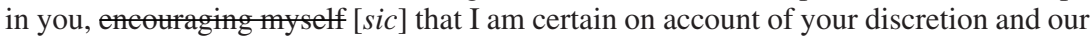
intimate friendship, you will endeavor that the right and proper thing be done for me. Until now, I have always had the help and benefit of paying a perdere, and if this were not the case I would be undone, and I would not do in this office such good as one might otherwise believe; however, that law they made of April and May that anyone could see is barbarous did me the greatest great $[$ sic] damage. I say no more. May Christ watch over you always. Prepared always to do your pleasure. In Florence, the 1st of August 1409

Donato Acciaiuoli, vicarius ${ }^{1}$

Acknowledgments: I am grateful to Vilna Bashi, William Connell, Susan Liebell, Ann Mische, John Padgett, Sidney Tarrow, and anonymous $C S S H$ reviewers for their helpful comments, encouragement, and corrections.

1 ASF, Carte del Bene, 49, 289, my translation. The original text is: "honorevole amico k'mo / di poi ch'io vi scrisse o sentito che voi siete di quegli ch'anno a sgravare le prestanze cio queste nuove della nuova distribuzione del nostro gonfalone / Et per tanto vi prego karissimamente bench'io penso e non bisogni voi m'abiate a mente per raccomandato / . . vero che nella nuova distribuzione io ne rimasi un buo' fiorino d'oro / e mezzo / credo sappiate assai dello stato mio debole il perche quanto più posso karamente vi prego che in questo m'aiutate e siate operatore con vostri compagni per quello modo /. . a a mme pare che mi sia levato quello mezzo fiorino sich'io rimanga col bene [text obscure] del fiorino col pagare perdere. Sopra di ci non scrivo più però ch'io o tanta speranza in voi e che mi rendo molto certo per la vostra discrezione e nostra intima amicitia / opererete mi sia fatta gratiosa ragione / et infino a ora o sempre auto il beneficio a pagare a perdere / che se ci non fusse io potrei rimanere disfatto / Io non far in questo ufficio quello utile ch'altri si crede però che quella legge si fece d'aprile e di maggio che non si potesse cognoscere incivile m'a fatto grandissimo danno / Altro non dico. Christo vi guardi sempre. Aparechiato sempre a vostri piaceri. dati Florenze il 1 dì di agosto 1409."

0010-4175/05/638-664 \$9.50 @ 2005 Society for Comparative Study of Society and History 
In this letter, Donato Acciaiuoli, a politically prominent but not particularly wealthy member of an esteemed Florentine family, writes to Riccardo del Bene, a richer but younger co-resident of the neighborhood of Vipera, looking for an insider's assistance in keeping his tax burden down. Donato paints his economic position bleakly, unwittingly conforming in detail with prescriptions provided in the now-famous contemporaneous memoir of Giovanni di Pagolo Morelli, written to urge his own heirs to hide their wealth and dramatize the fiscal injustices done to them:

Run to the Signori and lodge a petition to pay one-third or two-fifths [of your tax assessment] a perdere, or that the Signori and Collegi must correct your assessment, informing all of them of your incapacity to pay, and also advertising this to their friends; and thus put up a good fight. And if you're not able [to do this] at the time of a particular priorate, wait as long as it takes, since these are matters wherein he who persists in pursuing them, will have matters come around his way; or if they don't come around, demonstrate to everyone that you have been overburdened, and are unable to pay, and with that the next occasion you will have an easier time of it (Branca 1986:197, my translation). ${ }^{2}$

However, Acciaiuoli's relationship to the state is not so one-sided as Morelli's advice would lead us to believe. In fact, his letter exemplifies the widespread Florentine strategy of relying on personal relationships both as a defense against the demands of the state and as a means of remaining an active member of it. Florentine citizens were not merely subjects or "victims" of the state, but also its custodians. Thus, although Acciaiuoli protests that "anyone could see" the newly instituted tax law was simply unfair, he also alleges that he needs and wants del Bene's favor to continue to serve the commune honorably. He actively links personal and collective destinies: a favor to him is simultaneously a benefit to the commune. Loyalty between friends and loyalty to the collectivity are represented as mutually consistent.

Friendship and citizenship, patronage and the state - these were inextricably connected in a variety of ways in the Renaissance Florentine polity. ${ }^{3}$ One cannot adequately write the political history of fifteenth-century Florence without attending to both emergence of the state (or at least the reggimento) as an autonomous actor (Fubini 1994) on the one hand, and a surge in patronage politics (D. Kent 1978; 2000; Rubinstein 1997) on the other. In this article, I shall highlight two aspects of this state/patronage nexus, specifically as it pertains to

2 Morelli further advised his heirs to "draw near" to persons in positions of power: "make an effort to acquire one friend or more in your neighborhood, and do whatever good you can for him, and do not trouble yourself about putting yourself in his care" (Branca 1986:190; my translation).

3 For research on the importance of patronage in particular, see for example, D. Kent 1978, 1987, and 2000; Molho 1979 and 1994; Weissman 1982 and 1989; Fabbri 1991; F. Kent 1991; and Connell 1994 and 2000. See Conti 1984:105 and 114 ff., specifically on favoritism and tax assessments. One important way that friendship and the state were connected that I will not discuss is that the language of amicizia (friendship) was used equally in matters of state to identify allies of Florence, and in matters of factional politics to identify clients and supporters who together conspired to take control of the Florentine state. 
taxation, by common agreement a critical component in the development of the early modern state (Tilly 1975; Levi 1988). Both aspects should lead comparative historical sociologists and historians to rethink the history of the state in early modern Italy and the history of state development in Europe writ large.

First, fiscal pressures and fiscal institutional innovation in fifteenth-century Florence were very much interwoven with the consolidation of clientage-based politics. The catasto of 1427 (Herlihy and Klapisch-Zuber 1985), the plethora of ingenious schemes for encouraging citizens to pay back-taxes (Conti 1984: passim), the Monte delle doti (or Dowry Fund; see Kirshner and Molho 1977; Molho 1994)—were arguably "modernizing" innovations. They certainly depended heavily upon the sophistication of Florentine accounting practices (de Roover 1966; Melis 1991; Epstein 2000a: ch.2), and were premised (in communal debates) on understanding the state as having needs aligned with, but also distinct from, the needs of the citizenry. But to deal with the burdens imposed by these schemes for tax collection, Florentine citizens frequently and routinely turned to their fellow citizens for assistance. ${ }^{4}$ Patronage letters were an indispensable venue where these pleas for help in return for loyalty were expressed. Such letters became so abundant in the fifteenth century that we may regard Florentine patronage correspondence as a corpus of discourse characterized by recognizable tropes and patterns of discursive practices through which individuals sought favors (McLean 1998). ${ }^{5}$ Patronage did not simply signify the top-down distribution of material rewards, nor was it limited to the Medici family's well-known lavish support of philosophy and the arts. It was a pervasive, bottom-up, political cultural (Somers 1995; Eliasoph 1990) phenomenon-an institution in the sociological sense of a set of relatively routine or "standardized activity sequences" or "organized, established procedure[s]" that support and reproduce a set of shared expectations about the world and how it operates (Jepperson 1991:143, 145, 147). This emergent institution involved

${ }^{4}$ As Conti notes, "Il]e testimonianze di questo tipo [letters, as well as official petitions, admonishing recipients to help in obtaining tax relief] sono così abbondanti, da dare l'impressione che la città fosse colta da una agitazione febbrile ad ogni mutamento dei ruoli" (1984:115). Also see Molho 1987:207.

5 Among the stock elements of Acciaiuoli's letter are the opening words (" di poi ch'io vi scrissi"), the rhetorical turn that initiates the request for a favor ("Et per tanto vi prego"), the superlative framing of the request ("quanto più posso"), the open-ended nature of the specific actions the recipient is to take ("in quello modo"), the abrupt, almost embarrassed closing of the request ("Sopra di ci non scrivo piü"), the expression of hope in the recipient ("o tanta speranza in voi"), and the closing salutations ("Christo vi guardi sempre"; "Aparechiato sempre a vostri piaceri"). These exact elements are found ubiquitously in letters written throughout the fifteenth century. Acciaiuoli also explicitly portrays del Bene as his operatore, a noun linked to the verb adoperareto contrive, to make happen - found abundantly in Florentine patronage letters. Furthermore, Acciaiuoli sends mixed signals here typical of patronage interaction, mingling expressions of deference with claims to desert. He claims friendship, but denies the need to have invoked it. He writes, but denies the need to have written, since the two men's intentions are so naturally harmonious. For more on styles of patronage interaction, see Eisenstadt and Roniger 1984; Reddy 1997; McLean 1998; and Davis 2000. 
what we might call "traditionalizing" innovations in the conduct of interpersonal interaction - "traditionalizing" insofar as they were built upon personal loyalties that compromised the autonomy and efficiency of the state. Allegations of favoritism in distribution of the tax burden in turn prompted renewed rounds of search for more equitable (or at least politically feasible) methods of taxation. In effect, trends towards "modernization" and "traditionalization" at the level of social institutions developed simultaneously and in constant response to each other. ${ }^{6}$

The second aspect of the state/patronage nexus I wish to highlight is the way individual Florentines participated in both domains and managed these domains' disparate demands. As Conti (1984, esp. 119ff.) has documented, administrative change in the commune was accomplished within the constraints of a contest, not between state actors and civil society, but between citizens in their role as custodians of the state, and the same citizens in their role as subjects to the state. Members of the Florentine reggimento were fully implicated in, and had roles and identities based on, both sides of the (admittedly anachronistic) state/civil society conceptual divide. ${ }^{7}$ Patronage letters are critical for evincing the way clientelistic loyalty and commitment to the state were interwoven at the level of individual cognition and action. This combination of roles-custodian and subject-was empowering to some extent. The very modest separation of the state from the citizenry allowed tax exactions to be extraordinarily high, since citizens tended to identify the viability of the state with their personal well being to a greater extent than was true, or even conceivable, in more predatory states. But it also posed problems for state autonomy. As fiscal pressures grew, the rhetoric of personal loyalty among citizen "victims" of state policy grew stronger. And however desirable Florentine state-makers considered reform, they found it impossible or inconceivable to establish fiscal relations with the citizenry that would definitively decouple taxation from political participation. No sufficiently affluent group was sufficiently removed from political participation as to be viewed as the legitimate victims of a predatory state.

6 A confusion of analytically modern and traditional elements characterized Florentine political and economic institutions in a variety of respects. There was a bona fide "politico-juridical transformation" of the state (Fubini 1994); meanwhile, the distinction between public and private remained chronically blurred (Chittolini 1996). Respect for constitutional tradition was juxtaposed with an increasingly self-interested orientation among communal leaders (D. Kent 1987; Rubinstein 1997). Different parts of the contado simultaneously manifested 'forward-looking' and 'backward-looking' forms of landholding (Emigh 1998). Investments in agriculture were not inconsistent with capitalist underdevelopment (Emigh 2003). Innovative business organizational forms such as the holding company (De Roover 1966) and modern business practices such as current accounts and double-entry bookkeeping (Melis 1991; Dini 2001) emerged alongside of traditional conceptions of obligations to partners and fellow businessmen (Goldthwaite 1985; 1987) and a patronage-like market structure (Padgett 2001; McLean and Padgett 2004). And a smattering of locally negotiated contracts with subject cities persisted in the midst of the consolidation of the regional state (Fasano Guarini 1996; Cohn 1999; Connell and Zorzi 2000; Epstein 2000a; 2000b; Petralia 2000).

7 Epstein (2000a:32) also alludes to this issue. 
Consequently, the evolution of the early modern European state stalled in Florence, as many historians and comparative historical sociologists recognize. But this was not simply because of Florentines' overzealous commitment to capital or their lack of enthusiasm for erecting a territorial state, as Charles Tilly's (1992) model may suggest. Nor was it simply a function of the composition of classes and their distinct interests, as Hendrik Spruyt's (1994) model and, occasionally, Richard Lachmann's (2000) might lead us to believe. The stunted Florentine counterpart of the early modern state was not the product of a set of necessary and/or sufficient conditions, but the outcome of a number of concrete interactions (Molho 1996:103; Najemy 1991), both contentious (as emphasized by Tarrow 2004) and cooperative. And again, these happened at both the institutional and the individual level. Administrative innovations at the macro-level emerged and then were dismantled as an incremental and hesitant response to culturally shaped patterns at the micro-level of interaction in civil society. State institutions and interpersonal interaction styles co-evolved (Elias 1978).

Patronage, like other political cultures, was a "lived form" wherein "individuals reacted to constraints imposed by the emerging centralized state" (Ikegami 1995:8). As the demands of the state varied, so too did the cultural practices of patronage surge and vary. To elucidate this, the next section will summarize for non-specialists the vicissitudes of Florentine fiscal policy throughout the 1400s. Tracing the increases and decreases in state demands year by year provides a roadmap for selecting important periods in which to search for tax-related patronage correspondence. Such correspondence will reveal that the state and interpersonal relationships developed in a conjoined way. In the subsequent section, I will present and textually analyze a number of patronage letters pertaining to taxation and demonstrate changes in their content and style over the course of the fifteenth century. By means of these letters we may better understand both changes in the Florentine state and changes in interpersonal relations.

This analysis is made possible by the survival of tens of thousands of fifteenth-century letters in the Florentine state archives. ${ }^{8}$ In the course of several trips to Florence in 1990, 1991, and 1998, and dozens of hours of reading online documents over the last year, I selected a multi-year sample of patronage letters pertaining to taxation issues. ${ }^{9}$ Letters concerning tax relief, judging from

${ }^{8}$ Many of these, from the Mediceo avanti il Principato collection, are now available online (http://www.archiviodistato.firenze.it/Map/).

9 Given the vagaries of which letters survive, and given the volume of letters available to read, there is little way of knowing whether this sample is representative in any statistical sense. Furthermore, the content and style of each letter necessarily depends upon a host of factors: not only upon the legislative action or opportunity structures that catalyzed it, for instance, but also the economic circumstances of the supplicant and the structural relationship between sender and recipient. These contextual factors also make it hard to discern what a representative sample would look like. 
my canvass of the documents as well as studies by others (e.g., Molho 1979), are not the most frequently available type. Nevertheless, they provide a treasure trove of information about the intersection of state action and personal strategizing on a critical issue. And they offer crucial evidence of how Florentines were both actors in and subjects of the state, a critical factor in Florentine state development. The final section will return synthetically from detailed history to theory. I will briefly critique existing arguments in the comparative historical literature about why the development of the early modern state stalled in Italy, and then reiterate my own argument.

\section{THE UPS AND DOWNS OF FLORENTINE TAXATION IN THE I 4 OOS}

The landscape of fifteenth-century Florentine fiscal policy is littered with innovations and reversals, all produced by a need, well recognized by citizen-legislators, to distribute the tax burden equitably and effectively. Molho (1971; 1996) and Conti (1984) provide outstanding detailed accounts of this history, and so here I will present only an analytical summary for non-specialists, highlighting two pairs of contrasting points.

First, to be eligible for communal office, one had to have contributed to the Monte Commune, the city's funded public debt, and paid one's taxes in full. Because the city was continually unable to pay off its debts, ${ }^{10}$ contributors to the Monte were effectively creditors of the commune, and hence were implicated in its fiscal and political health. Regarding taxes, being in arrears (allo specchio) could cost one a chance at office for three, five, or even more years until another scrutiny to determine eligibility was organized. Those who anticipated being seen as fit for office by virtue of their family's status had to keep their tax record clean by whatever methods available. For these reasons, Florentines feared and had to defend themselves against the individual effects of taxation. ${ }^{11}$

10 This fact was widely recognized. Citizens reported the value of their shares of the Monte using officially sanctioned discount rates in their 1427 tax returns. Often they went the state one further, contracting prices for the exchange of Monte shares that reflected greater depreciation than the pegged rate (see for example, Catasto 68:144; 75:146). Given that the commune found itself perpetually scrambling to extract wealth from its citizenry at disadvantageous terms, one might think a more autonomous state would have been advantageous. Yet one could argue that Florentines remained loyal to the state in a way that a sterner, extractive policy of taxation would have jeopardized. On this point, see also Molho 1996:133.

11 A letter of 26 April 1431 from Ser Niccolò Tinucci to Averardo de' Medici (Mediceo avanti il Principato III, 121, but labeled number 122 in the published inventory) gives a sense of what the specchio list meant to contemporaries. He wrote, "Although I do not expect to be allo specchio for a variety of reasons, and also because the notary of the priors of our quarter indicates as much, that I am eligible to be drawn, all the same I am sending you there Piero this artillery soldier who comes to remind you. And in the event anything must be paid, I told him to come to you and you will give [the money] to him; so that if it were the case for any reason that I were allo specchio, which I don't believe I will be, I pray you that you will endeavor to pay that which is necessary, and write a note recording what you are lending, and I by the first mail will pay it back." Tinucci twice denies that he is really in danger of being placed allo specchio. He tries to adopt a businesslike tone on the topic, but his anxiety is betrayed by his repetitions, and his precautionary tactic of contacting Averardo. 
Second, however, many Florentines also feared the collective social and political consequences of taxation. Debates concerning the catasto-a method established in 1427 to assess taxes on the basis of extensive written inventories of household liquid assets and landed wealth (Herlihy and Klapisch-Zuber 1985)_reveal that leading citizens valued the plan not only for its equity and efficiency, but also because, in the words of Francesco di Lorenzo Machiavelli, after its implementation "the conspiracies, false pretences, and clienteles of the most powerful citizens will come to an end" (Conti 1984:132, my translation). Averardo de' Medici, a banker deeply embedded in the patronage networks of the Florentine establishment, praised it because assessments would be determined on sure evidence rather than uncertainty clouded with favoritism; thus it would contribute to domestic peace. The debate over the catasto was undoubtedly marked with inter-elite, class-like tensions (cf. Lachmann 2000). For example, a number of merchants were afraid that including liquid capital in the estimates of wealth would burden them extraordinarily. However, the cleavages in the debate did not follow class lines in any simple way. Later in the century, too, Cosimo de' Medici would oppose tax plans-for example, the diecina graziosa of 1442-that might have benefited him personally but would have destabilized the regime. Nicolai Rubinstein (1997:161-62) reports that Florentine leaders considered backing off on electoral controls in 1458 in order to facilitate passage of a new tax bill; evidently they saw the two issues as intricately connected. And in 1480, in the aftermath of an attempt on Lorenzo de' Medici's life, when the regime proposed the adoption of yet another balia (an executive body with extensive but fairly short-term powers that short-circuited participatory government), they secured consent for it with the promise of tax reform (Rubinstein 1997:226). The point is, it was not state officials standing outside of and acting upon society at large who debated fiscal policy, but rather citizens, discussing the apportionment of the tax burden amongst themselves. Theirs was a protracted effort to solve a key collective action problem of the polity, not a simple class battle.

The third point I will make is that one may postulate a certain governing dynamic to Florence's fiscal history. When the need for cash became more urgent, the imposition of forced loans grew, fewer citizens could meet these demands, and more of them had to pay discounted assessments and forego the interest owed to them. Alternatively, they could rely on others to pay on their behalf. ${ }^{12}$

12 Unpaid prestanzoni from the mid-1420s show up abundantly in 1427 catasto records. Among a group of 401 affluent and politically important households, 18 percent carried some kind of prestanzoni debt into 1427. The strategy of seeking grazie to pay fractions of the total tax due was quite common. Businessmen used their companies to pay personal taxes (e.g., Catasto 60:252; $65: 46,143,471 ; 68: 91 ; 76: 169)$, and some companies appear to have paid prestanze on behalf of their employees (Catasto $69: 107 ; 74: 15 ; 78: 68$ ) or out of customers' accounts (Catasto 79:85). There are also explicit cases of individuals assuming others' tax assessments in return for specified or unspecified interest. For example, Iacopo di ser Francesco Ciai claimed to have been owed 450 florins (expected value: 300 florins) by Giovanni di Cantino di Agnolo, regarding a house on the 
This tended to mean declining state revenue in the present (even as it reduced the state's long-term burden), which in turn increased the commune's desire for full-payment loans, and forced the state to offer more appealing terms to those citizens capable of surrendering large sums (see especially Molho 1971, but also Conti 1984:237). The result was that influence was consolidated in the hands of a few solvent citizens, a number of whom (at least in 1427) combined public administration of the fisc as Ufficiali del banco with private speculation on the future value of Monte stock. ${ }^{13}$ Cosimo de' Medici came to embody this dependence. On the verge of exile he addressed the Signorìa: "Ask your soldiers how many times they were paid with my own funds, the Commune subsequently repaying me when it was able to do so!" (Molho 1971:188).

My fourth point, however, is that this elegant governing dynamic overstates the clarity and unidirectionality of actual developments. The city faced dramatically different constraints over time; innovations did not stick. This led to a checkered history of oscillation back and forth between different off-the-shelf taxation procedures, between tax collection and tax relief, ${ }^{14}$ between innovative and traditional strategies for increasing tax revenues, and between periods of duress and relative ease for taxpayers. Figure 1 graphs this history succinctly, and provides important context for the letters that I will present.

The figure records the year-by-year fluctuations in the volume of forced loans imposed, which in turn correspond fairly closely to annual variability in military expenditures. ${ }^{15}$ Clearly, the most severe crisis was faced in the early

Borgo San Lorenzo which was rented out to Lodovico della Casa for 20 florins a year, the deed to which and the revenue from which had been transferred to Ciai by Giovanni di Cantino "in pagare loro prestanze" (Catasto 78:97).

13 The list of those engaged in such speculation includes: Giovanni di Piero Baroncelli, Iacopo di Piero Baroncelli, Antonio di Iacopo Canigiani (and his company), Neri di Gino Capponi, personally and through the firm he operated with Niccolo and Bernardo Giugni, which "had purchased many lots of interest payments due on Monte shares" (Catasto 65:97 and 73:110), Bartolomeo and Filippo di Giovanni Carducci and Filippo's son Francesco, Niccolo di Cocco Cocchi Donati, the bank of Toso di Albizzo da Fortuna and Giovanni di Orsino da Cignano, Giovannozzo di Francesco Pitti (on his own, but perhaps also in conjunction with his banking partner Antonio Canigiani listed above), Bartolomeo di Iacopo Ridolfi, Tommaso di Tommaso Sacchetti, Niccolo di Lorenzo Soderini, Bernardo di Antonio Da Uzzano, and Guido di Piero Velluti. A typical transaction was that struck between Canigiani and da Uzzano. Canigiani records that he is giving 40 florins to da Uzzano (as a premium), and da Uzzano is obliged in return to deliver (or receive, at Canigiani's discretion) 2000 florins worth of monte dei prestanzoni stock with a terminal date of December 1427, at a pegged striking price of 64 percent of face value (Catasto 64:101, 403). This futures market is another sign of the sophistication the Florentines achieved in the area of financial instruments.

14 It was common for the commune to initiate a tax rebate effort almost immediately after any new tax was collected. Conti suggests that the Medici made a habit of reducing the number of officials responsible for the assignment and collection of taxes after 1434, probably allowing them greater control of these impositori and facilitating a more circumscribed practice of favoritism. On the other hand, the number of sgravatori-officials charged with distributing tax rebates or reliefwas considerably greater, as in the days of the Albizzi regime, undoubtedly so that many more citizens experienced more directly and personally the supposed largesse of the Medici regime.

15 The actual amounts collected could depart, occasionally significantly, from the assessments imposed. This was especially true in the early 1430s (Conti 1984:81). However, for many years the 


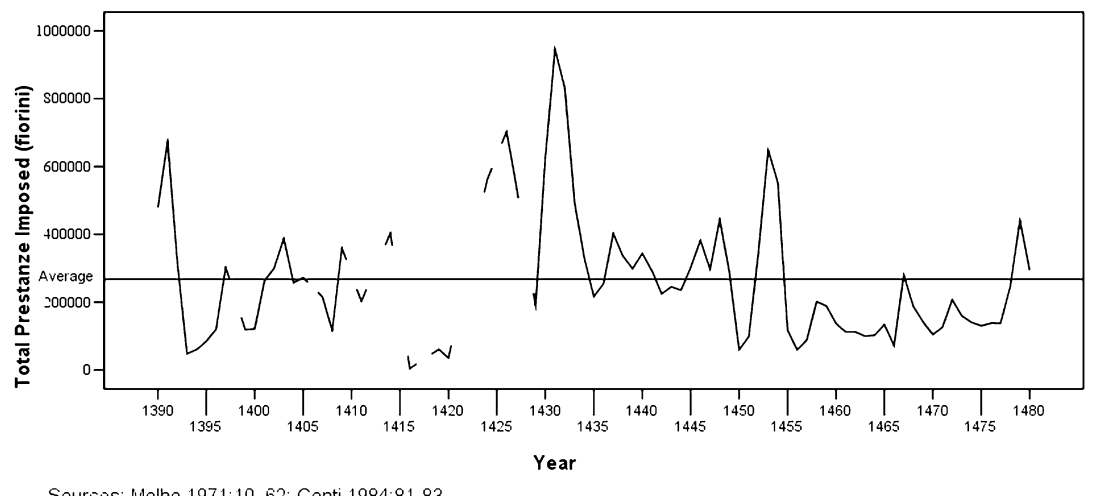

Sources: Molho 1971:10, 62; Conti 1984:81-83

Figure 1. Florence's fluctuating tax burden, 1390-1480.

1430s, during and in the aftermath of the war with Lucca. This crisis was exacerbated by having followed closely on the heels of the war against Milan in the mid-1420s. Other peak periods include the early 1390s (again a war against Milan) and the early 1450s (more wars, against Milan, and King Alfonso of Aragon). There are smaller but significant jags upward in 1403, 1409, 1414, $1437-1438,1440,1446,1448,1467$, and 1479 . I proceeded by assuming that these would be apt years in which to look for letters documenting how the tax situation affected interactions among citizens, and how communication about taxation signaled continuity and change in the texture of the state over time, and I sampled from them accordingly. ${ }^{16}$ I argue that interpersonal politicking constrained state action and shaped the spirit and understanding of governance. A study of concrete communications between actors in this drama, scattered across the fifteenth century, will help to bring home this point.

GROUND-LEVEL RESPONSES TO FISCAL DEMANDS

All of my said goods have been sold for the Commune ... in my absence, since I took off so that I wouldn't find myself put in prison; and besides these goods, all my shares

difference appears to have been less than a 20 percent shortfall. Focusing on assessments rather than yields permits one to examine fluctuations over a longer period. Figure 1 also suggests that the most significant antidote to Florentine fiscal ruin would have been diplomacy: keeping out of wars, such as during the $1454-1478$ period, did more to stabilize the regime's finances than any innovative administrative actions could have.

16 Herlihy (1991: Fig. 8-mistakenly referred to as Fig. 9 in his discussion of it) documents that the number of citizens disqualified for the Tre maggiori because of tax delinquency rose and fell more or less in lockstep with the fluctuating demands of the state, except in two respects: (1) in general they lag slightly behind the years of heaviest taxes, as if citizens could keep up with heavy assessments for some period of time before running short; and (2) a great number of citizens were found to be in arrears in the mid-to-late 1440s, even though the tax burden at that time was lighter than it had been in the 1430s, and than it would become in the early 1450 s. 
in the Monte were sold; and besides this, I find myself debtor of the Commune! . . So that one can see what justice this is, that everything I had were taken, and remaining in such debt that if I were not supported by my uncle Francesco, I would die of hunger. And I am [only] twenty-five years old (Conti 1984:310, my translation).

We have brothers trying to scratch out a living abroad, not being able to stay in Florence on account of the taxes (Conti 1984:343, my translation).

These laments made to tax officials by Filippo di Benedetto dei Nerli in 1442 and Matteo di Giovanni Strozzi in 1451, respectively, demonstrate how Florentines felt about the periodically egregious tax assessments of the commune. They also provide some evidence of state tactics, and of certain strategies Florentines adopted to cope with state demands. Expropriation and imprisonment are hardly the benign acts of a weak state. And yet the state's often ingenious efforts to collect funds from the citizenry continually drove citizens to seek financial help from their fellow citizens, with the consequent reinforcement of interpersonal attachments that posed a challenge to the state.

In what follows I present more than a dozen letters, all in one way or another about problems with taxes. They are presented in chronological order so that readers can follow several changes that occurred over time. One was a shift from citizens being proactive in reducing tax assessments to their becoming more reactive, asking for assistance in paying debts already owed. A second was that the balance between expressions of desert and expressions of deference shifted toward the latter after 1434, at least in letters addressed to members of the Medici family. Third, there appears to be a move away from writing to people who were directly involved in the taxation process and toward seeking help from those only indirectly involved. The latter two changes jive well with what historians have recognized for some time: that there was a concentration in the personalistic practice of power in Medicean Florence. Extrainstitutional channels had arisen to challenge state administrative control over fiscal outcomes, thus weakening the autonomous power of the state.

However, we will also see that there was over time a consistent pattern whereby the problem of tax collection was linked to performance in office and/ or the desire to hold office. This link existed at the level of communal policy, and consequently it is found also in the substance and rhetoric of interpersonal interactions. The relationship of Florentines to the state was both adversarial and participatory, and this is an absolutely critical factor in understanding why rationalization and autonomization of the Florentine state stalled. The margins for state action were always tightly constrained by the competing (but shifting) involvements of Florentine citizen participants.

This article began with Donato Acciaiuoli's letter of 1409, a year of heightened taxation. The next such year for which data is available is 1414. Data are missing for 1413, but the following excerpt from a 17 October 1413 letter fromby Filippo Dall'Antella to Pippo di Franco Sacchetti suggests similar pressures 
were in play (Conventi Soppressi 78, 324:108). Like Acciaiuoli's letter, this one is redolent with Morelli-esque sensibilities: "My honorable elder and dearest father, I wrote another letter to you in the past few days, a letter which I do not know if you received. Now [again] I recommend to you my affairs concerning the prestanzone, that I not be treated as I was with the prestanze; you know how much I was treated unjustly. And I hope to be to you, Pippo di Franco, everything that you would like."17

Note here the combination of familiarity, or aspirations to familiarity, in the body of the letter, with rather deferential framing at the beginning and the end. The tactics of rhetorical deference and rhetorical brinkmanship ("you know how much I was treated unjustly"), so notably mixed in the practices espoused by Morelli, are combined here. The letter melds the two cognitive components of clientage-deference and reciprocal obligation-into a single interaction. Also present here is something quite common throughout Florentine correspondence - the metaphorical equation of the patron with a father, with the attendant implication that patrons are expected to carry out the same duties of protection and guidance in public life that a good father ought to provide. Nevertheless, this letter's rhetoric is not particularly florid.

Moving ahead a decade, the next example provides evidence that patronage networks had become activated to deal with the tax burden. Pagnozzo di Bartolomeo Ridolfi, member of a distinguished patrilineage and head of a moderately wealthy household (Catasto 66:97), wrote to Averardo de' Medici on 18 February 1424(25) (Mediceo avanti il Principato I, 64), not about his own tax problem, but that of an underling ${ }^{18}$ : "Thanks for working that favor for me. I might seem ungrateful, but I am informed it was the cause of my being able to come back to Florence, which is a great consolation to me. Now the reason for this letter is to recommend to you Antonio di Niccolo Benucci, this little guy who I recommended to you another time. He is coming to lodge his petition concerning the prestanze, as in person he will advise you. He is poor and cannot pay; may he be recommended to you ... Say hello to Giuliano and Alessandra for our part."

This letter lacks the somewhat indignant tone of our previous examples, undoubtedly because Ridolfi is writing primarily concerning someone else's peril rather than his own. What is noteworthy is that Ridolfi portrays himself as

17 "Honor maggior et carissimo padre mio / Per un altro nei dì passati vi scrissi, la quale non so se voi avete auta per sì o nno. Per questa vi raccomando i fatti miei circa di fatto del prestanzone, ch'io non sia trattato come fui della prestanze; che sapete quanto io sono intrattato ingiustamente. E spero di essendovi pippo di franco tanto quello che(?) voi vorrete."

18 A note on the dating: the Florentine year was considered to begin on $25 \mathrm{March}$, the Feast of the Annunciation, and hence letters written before that date, like this and some others cited in this paper, are dated as if it were still the previous year, although we would date them in the subsequent year. I have already noted, letters in the Mediceo avanti il principato collection in the Florentine State Archives are now available on-line. Interested scholars may consult them there, and so I do not provide transcriptions here. 
close to Averardo and somewhat distant from Benucci. Benucci is "this little guy" who is poor ("in miseria"); by contrast, he addresses Averardo using the familiar " $t u$ " and makes a point of his personal acquaintance with Averardo's son and daughter-in-law. ${ }^{19}$ Although Ridolfi says that returning to Florence was a great consolation, he does not express his thanks dramatically.

The Medici were not the only targets of requests for tax help in the 1420s, as the following letter of 26 June 1427, from Marco di Simone Strozzi to Giorgio Cristofani, attests (Carte Strozziane, III'e serie, 132:277). Note how social distances are constructed rather differently here than in the Ridolfi letter. For one thing, Strozzi makes explicit that he is writing at the behest of his friend Ferrantini, not some "little guy." "Dearest elder brother, My friend Mariotto Ferrantini has heard that I have trust in you. I myself am certain of this and so in service to him I am writing to you, praying that it be pleasing to you to look favorably on him, to collect certain monies he is owed by debtors of his employed at your court. For he cannot take care of his needs, nor contrive to remit his prestanzoni, which, if not paid, will prohibit him from leaving the country. When you write to me about anything, write to me concerning this. Nothing more. I am always at your disposal ..." "20

Strozzi deliberately addresses Cristofani lovingly and deferentially as a dear older brother, using formal terms of address throughout. He begins the letter by putting the responsibility on Ferrantini for initiating the request and claims that he himself is motivated by his desire to do what friends do for each other. Only secondarily does he assert his certainty that Cristofani will be willing to help. "I am always at your disposal" is a typical stock letter-ending, and "praying that it be pleasing to you to look favorably on him" is a typical deferential framing of requests for help in fifteenth-century patronage correspondence. Still, these are not counterbalanced in this letter with forceful claims of deserving assistance.

There can be little doubt that the early 1430s were the period when Florentine taxes were most onerous. Accordingly, the rhetoric deployed in requests for assistance became more florid and urgent. In a letter written on November 14, 1430, by Federigo Sassetti to Niccolo di Iacopo di Ubertino Strozzi (Carte Strozziane, III'e serie, 113:94), Federigo explains how Lionardo and Bartolomeo di Ser Tino had formerly paid his expenses "out of kindness" (per loro

19 The strategic use of pronouns and deictic expressions such as "here," "there," "now," "then," "together," "with me," and so on to represent the social distance between writer and recipient and establish continuity in their relationship, is particularly salient in patronage correspondence (McLean 1998).

20 "Karissimo fratello maggior. Mariotto Ferrantini mio amico a sentito ch'io posso [text not clear] assai. Di questo $m[$. . . ] ando certo. E però, in servigio di lui, vi scrivo pregandovi che vi piaccia essergli per modo favorevole a riscuotere al questi danarinza avere da suoi debitori alla vostra corte sottoposti. Che non possa fare i suoi bisogni nè gli a operare in altro che n'aconciare suoi prestanzoni i quali, non pagando, non può uscire la terra. Per delib . . scrivetemi da nulla, scrivetemi di questo. Ne altro. Sempre a piaceri vostri." 
benignità), but now they would not pay them any more. Consequently, he wrote, "I have no other recourse but to you, and for this reason I pray that you do your best in any way that occurs to you, that on the 8th of December, which is the day the rent for my place is due, that you make to pay the money there at Florence where Lionardo Gondi indicates, and this I pray of you as much as I know how, such that if the need [I have] and the adversity [I face] were not so great, I would not beg this of you." 21

Now we are getting to the core patronage-style language that appears across the board around the time of the catasto. "I have no other recourse but to you:" the recipient is portrayed as the only possible helper available. "I pray that you do your best in any way that occurs to you," and "I pray of you as much as I know how": the repetition of the verb pregare - admittedly a common word, but one which a character in Leon Battista Alberti's I libri della famiglia claims all self-respecting Florentines should shun (Alberti 1969:68)—had become a stock element of requests for help. Likewise, the word "to beg" (gravare), another highly deferential cue, becomes increasingly common in patronage correspondence (McLean 1996). Finally, "need" and "adversity" are identified as motivating this request, rather than the fairness or justice cited in Acciaiuoli's letter. Thus Sassetti writes from a relatively supine position, one emerging directly from the extent of his need and the extremity of fiscal pressures, but also considerably determined by the changing culture of requests for favor in the 1420 s.

More of this change is evident in the following letter of 23 May 1431, written from the prison in Pisa by Giovanni di Pagolo Cantucci to Matteo di Simone Strozzi (Carte Strozziane, III'e serie, 112:65). Cantucci requests that Strozzi act in such a way that they be saved from undeserved injury and shame ("il danno e lla vergogna"), and that they be served with a grazia or licenzia to set their financial affairs straight. ${ }^{22} \mathrm{He}$ continues: “. . . and so I pray of you for grace and for the love of me and on account of reason, that you contrive with the

21 "Ne altro ricorso se nnon è a voi, e per detta ragione vi priego v'ingegnate per ogni mo[do] vi pare a dì 8 di decembre 1430, che sia el tempo del fitto del luogo mio, voi facciate pagare $i$ d[anari] là a firenze dove indica Lionardo Gondi. E di questo vi priego quanto so che non [es]sendo il bisogno e l'aversità quant'ebbe non vene graverei."

22 Besides the licenzia, various other written instruments such as the bollettino, the sicurtà, and the salvacondotto were sought by those in tax arrears (or facing other kinds of obligations) in order to secure a certain period of exemption from prosecution or incarceration, to liquidate their assets, and to settle their debts (Conti 1984:307). For an example of the salvacondotto, see Mediceo avanti il Principato XII:132, Baldovinetto di Alesso Baldovinetti to Cosimo de' Medici in Florence, 9 October 1435. Baldovinetti calls himself Cosimo's "least servant," and claims to have been "most loyal" to Cosimo in the hopes of obtaining a salvacondotto while his tax petition was pending. An example of the request for a bollettino is Antonio Baldesi's letter to Forese Sacchetti of 12 November 1418 (Conventi Soppressi 78, 324:171), in which he begs Forese, on behalf of Agnolo di Francesco de Pulciano, "that, retaining your honor always, it might be pleasing to you to concede a bollettino to Agnolo so that by means of this the said Agnolo is able to come there safely" (conservando sempre onore piaccia concedergli uno bullettino sichè mediante quello il detto Agnolo possa venire costà sicuramente), in order that he might pay off his creditors bit by bit. 
friends and the Ten that in some way we are released from this place, and we will be obliged to you . . . I pray of you that you recommend me to our friends, and to Luigi di Piero Guicciardini, that he pay my catasto assessments, because I hear that it would be advantageous; I pray that if he doesn't take care of it that you will." ${ }^{23}$ His follow-up letter of 26 May is similar, begging Strozzi to recommend his case to "our other friends," and continuing that he had himself written to Marco degli Strozzi and Luigi Guicciardini. "Help me, for God's sake," he concluded (Carte Strozziane, III'e serie, 112:66).

As in earlier letters we have examined, Cantucci proposes multiple justifications for demanding assistance - here both love between writer and recipient, and the reasonableness of the request. But there is, in addition, a direct expression-even a promise — of obligation and future payback attendant upon receipt of assistance. Unlike the first letters we examined, this writer explicitly invites the recipient to activate a network of friends (amici) on his behalf. In the first mention of the word, Cantucci refers to "the friends" (gli amici), suggesting a more or less impartial group of potential helpers. But in the second instance he asks to be recommended to "our friends" (agli amici nostri), suggestive of a more bounded, exclusive, and potentially partisan grouping of loyalists. Friendship (amicizia) was an ambiguous term (Trexler 1980; Weissman 1982), carrying the sense of both sentimental attachment and political partisanship. Here, too, with the references to Luigi Guicciardini, we find explicit reference to a pattern that had by this time become widespread-that of enlisting others to pay taxes on one's behalf.

No doubt it was prudent for those making requests to develop as many potential friendly contacts as possible, hoping that one of them might come through, or even that the more patrons back home in Florence who were apprised of one's situation, the greater the likelihood that one's need would be discussed in their conversations. In this way, too, those making requests sought to frame their problems in terms of matters of collective importance. Surviving letters of the Strozzi make clear how much that family cooperated to ensure that taxes were paid on time. ${ }^{24}$ The patronage network assimilated itself to a family network in its effort to meet the public financial obligations of its poorer

23 “. . . però ti priego di grazia e per amore di me e per la ragione che tu adoperi con gli amici e col dieci per modo che di questo parzionali siamo rilasciati, e esserti obligato . . . Priego ti che mi raccomandi agli amici nostri / inverso luigi di piero guicciardini che paghi e miei catasti perchè sento vagliono vantaggio priego ti se non lo facesse lui lo faccia tu."

24 See Carte Strozziane, III'e serie, 132:161, 186, and 196, all from late 1425. In the first, Piero di Carlo writes to Matteo di Simone that a certain Ser Filippo had been charged with paying Piero's prestanzoni; but in the event this had not been done, he asked Matteo to take care of it, entreating him, "Do not forget this, because I would not like to end up in the company of magnates, nor allo specchio." Biagio Strozzi wrote concerning his own tax problems, recommending himself to Matteo because "I am completely certain that you will act in this matter as if it were your own affair." Nanni Strozzi's brief note to Matteo comes from the other side of the request ritual: "Your diligence concerning my affairs is that which merits the affection I have for you. I thank you for the money that you provided that I should have." 
clients. In so doing, the patronage network did not always completely frustrate the state's efforts at raising revenues, but it gained another purpose which rendered its adherents more completely attached to it than to the collectivity as a whole. Practitioners of patronage also became increasingly adept not only at managing their members' resources, but also at hiding sources of wealth from communal officials.

Tax difficulties were beginning to affect ever-higher echelons of society. The Tornabuoni family, in-laws of the Medici and among the very richest households in the city in 1427 , experienced a 45.4 percent drop in their net fortune between 1427 and 1431 (Conti 1984:88). No wonder, then, that Francesco Tornabuoni wrote to Averardo de' Medici (his niece's father-in-law), from Cascina on 19 June 1432, using the same kind of urgent language that Federigo Sassetti had used with Niccolò Strozzi, asking Averardo to help him with a pressing financial problem: "Respected and honored brother, Yesterday I received a letter of yours of the 16th of this month, to which I respond now, praying that it be pleasing to you to contrive by all means available that I obtain permission (licenzia) to return to Florence because the necessity of tending to my affairs presses me to be there. I am still mindful of what you write concerning the Monte money. For this too it is necessary for me to be there . . Nothing else for now, except that I pray and beg of you as much as I am able that you contrive that I may come back there ... " (Mediceo avanti il Principato V, 229). This letter was followed by another six days later:

Respected and honored brother, Many letters I have written to you praying you to contrive by all means at your disposal that I may leave this place with permission, because I am under pressure with so many matters as you surely are sufficiently informed. And yet I still have heard nothing. And for this reason, again, as much as I am able and know how to, I pray that you act in this matter as much as is possible for you, since I am not able and do not want to stay here any longer. And advise me if you believe that coming back without permission were tantamount to throwing myself in the jaws of the podestà. I say no more except that I pray of you and plead with you as much as I am able that you act so that I may come back to my home there. At your pleasure (Mediceo avanti il Principato $\mathrm{V}, 232)$.

Yet another letter was written three days later, virtually identical in character (Mediceo avanti il Principato V, 234). In all of these Tornabuoni seeks a licenzia-a document signifying official permission of the commune to return to Florence in order to tend to one's financial affairs and cover one's debts to the city. Although he does not indicate that he was acting in any official capacity on behalf of the commune at the time, Tornabuoni's letters from this period do suggest that he was aware of and even involved in Florentine troop movements and needs. Thus, at least in an implicit way, his correspondence sits astride the goals of service to the commune on the one hand, and evasion of state coercion on the other.

Tornabuoni begins each letter with a standard opening salutation that emphasizes Averardo's obligation to him through the trope of parentado. All three 
letters employ the "ti priego" formula, and in fact repeat it a second time to achieve a more plaintive quality. The expression, "I pray as much as I am able and know" (priego quanto posso e so), is a very common turn of phrase in patronage correspondence throughout the fifteenth century, yet the superlative quality of this figure of speech was undoubtedly intended to heighten the impression made on Averardo.

In a letter of 5 November 1431, another Medici partisan, Bartolomeo Orlandini, wrote to Averardo seeking assistance on a financial matter pertaining indirectly to the crushing level of taxation in effect in the city. This letter demonstrates another facet of the link between taxes and political partisanship: some writers asked bankers to purchase government bills or borrow state revenues on their behalf for the purpose of meeting impending private financial obligations.

Magnificent sir and honored like a father / The strong storm affecting my city, together with the unbearable taxes that our citizens face, forces them and you and I to adjust our intentions. And the reason [for this letter] is that the heirs of Filippo Fagni are owed by us approximately 170 florins and Davanzato [Davanzati] about 80 florins all because of the dowry of Luigi my brother, and that we still have to return to them this amount. They put me one night before the ufficiali dei pupilli and accused me. To defend myself any more I cannot do without great shame and injury, and going allo specchio. And because I am certain that you repute my honor to be yours also, I pray that you be content to write to Giuliano or to Piero who holds the ledger, that they purchase some of the advances from the acatti [forced short-term, reimbursable loans to the city]. And that they record a promessa [written obligation to pay] in my name, such that at the time they need this quantity of money back, they will be paid. Do not touch any of my principal, because this is owed to Rinieri del Fiogia. I pray that you do this quickly because from day to day I am trying to keep the podestà from banishing me. And he has given me only a few days to give him a response. And for all of this I pray of you that you relieve me of this shame. May God in all things concede to you that honor that we and your friends desire. All of your family are healthy here (Mediceo avanti il Principato V, 14).

Orlandini's large household had listed significant debits in its 1427 catasto declaration, but their gross assets placed them among the top four hundred of the city's 9,780 households (Catasto 79:151). Clearly, the tax burdens imposed by the state drastically reduced liquidity in the city and caused citizens to fear for their own standing, forcing them to resort to ever more complicated strategies and manipulations of the tax system. As with earlier examples, this request is first framed in terms of family ("Magnificent and honored like a father"), although here we see a far more deferential rhetoric than Dall'Antella or Tornabuoni used. Orlandini acknowledges the great shame (vergogna, the opposite of honor, onore) that he faces $;^{25}$ then, adopting a fairly standardized formula, he equates his honor with Averardo's own. Orlandini strategically invites Averardo to infer the worthiness of his petition, and the trustworthiness of himself, from the coherence of his reference to widespread understandings of honorable behavior. Were he not desperate, Orlandini would not make this re-

25 Cantucci, above, referred to the vergogna e danno he faced; Orlandini refers to danno e vergogna. 
quest-he would not jeopardize what honor he presently enjoyed on the basis of his wealth, political position, and moral independence. This disclosure of earnest desperation enlivens the letter, but it also is animated by and in turn revivifies the sense of honor on which the whole system ultimately rests. Orlandini concludes his letter in a rhetorically conventional way, repeating the " $v i$ priego" formula. However, he also refers supportively to the amici of Averardo-seemingly indicating the political clients of the Medici and their collective agenda, even as he distances himself from them by referring to himself and/ or his family as somehow distinct from the rest of the amici. Thus here we have examples of stock forms of patronage correspondence, but also evidence of how the state's inventive tax programs "infiltrated" private relationships.

As Figure 1 indicates, after 1432 the burden of forced loans tapered off dramatically, and yet the high taxes left an indelible mark that became more evident with successive small increases in tax exactions from the late 1430s into 1440. This comes through in a letter of 4 February 1439(40) from Lionardo di Antonio de' Nobili to Cosimo de' Medici:

Dearest honorable brother, One may say that I and my son, your godson (tuo figliaccio), have become country dwellers. For a long time, I have not been able to enter the city on account of the enormous taxes I owed in the past, and if it had not been for the novina and the ventina [of 1434 and 1437 respectively, procedures for tax collection resurrected from the early $1400 \mathrm{~s}$, prior to the adoption of the catasto] one would no longer have any recollection of me or my son ... I am often not able to make my payments, so that often I find myself $a$ specchio, and for about sixteen years, one could say I have found myself and find myself [in that condition]. And I have a great hope in this new distribution of the settima (of November 1439), that they will give good and perfect consideration of my impossibility of paying ...

Nobili continues, explaining that his family has often had to resort to living off of the woods. But soon he comes to his main point: "I hear that it has been arranged that a new imborsatione [i.e., a collection of names eligible for office] concerning the offices of the palace, both domestic and abroad, is to take place. I am certain that you and your sons need expend little effort (bisogna durare pocha fatica) by honest means, and so I want to pray of you, with your friends, that you contrive that your godson not be consigned to oblivion (dimenticatoio)."

Despite the decline in tax pressures, many citizens still suffered on account of them. Sometimes they bore this suffering for a period after taxes were levied, but eventually the strain caught up with them. Consequently the techniques for overcoming tax problems in pursuit of communal office remained in place, arguably with a heightened rhetoric of deference towards those whose influence had grown enormously. More intriguing still, Nobili openly suggests in his letter that he believes he owes his survival to the dismantling of the catasto and its replacement with more traditional methods of collection, beginning in the early 1400s. These methods - the novina, the ventina, the settima-enhanced the exercise of favoritism. Nobili may have believed that the Medici themselves 
were instrumental in this change. Now he reminds Cosimo (who appears to have had no direct role in the distribution and collection of the new tax) of his terrible situation, hoping once again to get relief and, more than that, re-enlistment, for his son if not himself, in the register of potential office-holders. To accomplish this he flatters, writing that he is certain that it will require "little effort" on Cosimo's part to pull this off. By now we have come quite a distance from Donato Acciaiuoli's petition to Riccardo del Bene, who at least had been one of those actually charged with distributing the tax burden.

A letter written on 30 November 1441 to Cosimo's son, Piero, by Giacomino Tebalducci, introduces one further level of remove into the chain of tax-related favor-seeking. It is not the letter's recipient who is to provide assistance, but the recipient's father:

Noble sir and honorable friend, In this present life all of my hope remains solely in you. Thanks be very much to God who has clearly shown me, by means of you, that I must get out of the terrible shadow I have been living under on account of my insupportable taxes, and get my burden reduced to a more just level. For your information, we . . remain debtors of this commune for catasti and ventine and settime 590 florins or more in total, and we have but seven small farms remaining to us. Therefore, humbly I pray of you, make known to your venerable father not only our need, but also [indicate to him] that he could not help any man who would so much desire to see the satisfaction of all those matters that pertain to your advantage and your honor (l'utile e l'onore vostro) as Giacomino does ... Our affair could not be more insignificant in comparison to his great power (Mediceo avanti il Principato XVII: 24).

Again we see that the catasto's effects persisted a decade or more after its inception. And again, a writer provides multiple justifications for receiving assistance: his past burdens have been unjust, he has a great need, he desires that the Medici enjoy profit and honor (two desiderata routinely paired rhetorically throughout the fifteenth century). Furthermore, the assertion, "In this present life all of my hope is in you alone" recalls Federigo Sassetti's claim that "I have no other recourse but to you." Nevertheless, we detect here yet another increment in the hyperbole of patronage-seeking communication that exceeds what we have seen: in none of our earlier letters is the "power" (potere) of the patron so explicitly recognized.

In the late 1440s, tax exactions surged again, particularly in 1446 and 1448 . A variety of letters in the correspondence of Bartolomeo Cederni (see F. Kent 1991) deal with this new yet familiar climate, including a letter from Cederni's friend, ${ }^{26}$ Bernardo di Zanobi di ser Zello, in February of 1446(47), to Pagolo di Zanobi da Ghiaccetto (Conventi Soppressi 78, 314:264). Once more, even as past tax procedures were repeatedly consigned to the dusty bookshelf of Florentine fiscal policy, they lived on in the memory and the discursive practice of Florentine citizens for many years, and provided a warrant to justify assistance in terms of past injustices:

26 Other letters (Conventi Soppressi 78, 314:252, 265; also see F. Kent 1991:61) demonstrate that di ser Zello relied on Cederni extensively in managing payment of his various taxes. 
Honorable brother, As you know much better than I, the graziosa [an unpopular tax implemented in 1442 and thought to have encouraged fraudulent declarations] put me on the bottom, and this burden that they are arranging is likely to undo me, because debts are not deductible, and I will have a tax burden that is not justly mine. And also when they did the first catasto I had a debt bigger than was registered to me, so that I had credits I had to sell or give away to those who needed them, paying out a good part of my assets. And with this one, I made a high estimate, since my debt and the personal deductions I have would cancel everything, but still this estimate imperils me, and having obligated all of my income to my creditors, it is necessary for me to act subtly if I want to keep my family alive ....

This letter, rather than being purely a plea for help, functions more like a venting of frustration to a friend or associate, driven less by fear than by annoyance. Thus later in the letter Bernardo writes, in reference to the possibility of becoming allo specchio, "use your ingenuity and contrive that I not have to deal with this nuisance" (noia). Further, Bernardo asks da Ghiaccetto to confer with the powerful patron Neri di Gino Capponi to initiate the process of having his tax share reduced, and yet he also writes toward the end of the letter, "I am not writing to Neri [directly] so as not to give him any annoyance" (tedio).

Herlihy (1991:Fig. 8) has documented a considerable increase in the number of citizens disqualified on account of tax arrears in the late 1440s. And the chronicler Giovanni Cavalcanti claimed that the jails were full of people who had not paid their taxes around 1446 (Conti 1984:209). And yet, could it be that the threat of being allo specchio was becoming, at least for some citizens, an empty one, a routine "nuisance" rather than a catastrophe? It seems likely that this was no longer deferential patronage correspondence but simply the way friends expressed the problem to each other in their informal interactions.

Remarkably, it is hard to find letters concerning tax relief from the early 1450s, when the burden once again reached epidemic proportions. Therefore, I will skip ahead to 1479 for my final example, this time a letter from an eponymous descendant of Giovanni Morelli, the early fifteenth-century diarist whose advice to his children included explicit directions for hiding wealth and lamented unjust and excessive tax burdens. This later Giovanni Morelli wrote to Lorenzo the Magnificent on 15 April 1479, during another year of heightened taxation. Once again, tax matters and eligibility for office are completely interwoven, very much as they were in Lionardo di Antonio de' Nobili's letter of 1439. He even uses the same imagery of oblivion as Nobili did to describe his plight:

Upon my departure from there, I requested by your grace that it be pleasing to you to lend me such favor, that this time around I were eligible to be drawn for gonfalonier of justice, for the reasons I have many times said to you and which I know are well-known to you. And especially because in my house for so long there has not been any office holder, so that it is fair to say we suffer oblivion (essere nel dimenticatoio). And once again, it is on account of the taxes running back [in time] — that which affects me is about nine hundred florins, and I recognize this to be our undoing. And although I am of a firm will and opinion in wanting to make every effort, and in order that I have the pleasure 
of comforting my brothers, that I had done my utmost for them, once again I pray of you that you concede to me this favor (gratia), by means of which I will repute myself to be like one resurrected from the dead (un rilevato di terra), and I will put this on the list of other obligations I owe to your Magnificence (Mediceo avanti il Principato XXXVII, 219).

Here we find similarities with earlier letters, but also noteworthy differences. Whereas Nobili referred to Cosimo, only five years his junior, as a brother and addressed him familiarly, Morelli here uses formal language with Lorenzo, even though they are the same age. More importantly, whereas Nobili indulged in the traditional griping about taxation and cajolery to enlist the support of a patron, this is mostly absent from Morelli's letter. Furthermore, Morelli uses especially powerful language to convey the extent of his indebtedness to Lorenzo, a not uncommon rhetorical style in late fifteenth-century Florence. This language is part and parcel of the project by which persons subject to state fiscal predations sought relief by means of interpersonal favor-seeking, placing frontand-center their desire to serve the commune as participating citizens.

\section{TOWARDS A SYNTHETIC READING OF THE EVIDENCE:}

\section{SOCIETY AND STATE IN FLORENCE}

A handful of documents do not a conclusive argument make. Nevertheless, they do reveal a pattern of behavior and of discourse whereby Florentines turned to their powerful fellow citizens for assistance whenever they were heavily burdened with taxes. This game of deference and demands, in which Florentines made explicit or implicit offers of return favors or personal loyalty to wouldbe padroni, was already in place before 1400 , but became especially urgent in the 1420s and 1430s, precisely around the time of the introduction of the catasto, widely recognized as the fifteenth century's most innovative and forwardlooking piece of tax-related legislation. Rather than evaporating, the culture of patronage remained, and the legacy of the catasto lived on in later tax-related correspondence. Florentines regularly commented on and devised tactics for coping with the various demands of the state in their private letters. Furthermore, certain phrases and tropes appear with some regularity in these letters. They seem similar enough for us to say that the Florentine practice of favorseeking in the face of demands made by the state was in some sense institutionalized - that is, it involved a set of widely used procedures that continually reproduced a set of shared expectations about the world of Florentine politics.

Undoubtedly there were changes in the texture of this institution over time. For one, citizens switched from proactive strategies for avoiding high tax assessments to reactive strategies for paying off crushing tax burdens. Ironically, the catasto was meant to eliminate favoritism in the distribution of the tax burden, but it could not eliminate favoritism in the repayment of individual assessments. In examining letters over time, we can see a shift in the direction of more expressions of deference toward recipients and relatively fewer expres- 
sions of desert, at least when letters were addressed to one of the Medici. Finally, decisions regarding the distribution of taxes increasingly were made informally by persons other than those officially assigned by lot to handle the task. Virtually whenever the tax burden increased and/or methods for assigning shares of that burden were altered, individual Florentines responded with critical commentary on state policy and sycophantic letters to private citizens who could help them.

Consistently across many decades, though, the challenges the state faced with respect to tax collection, and the difficulties citizens faced with respect to tax payments, were intimately tied to office-holding, both at the level of official communal policy and within the confines of personal correspondence. As I have noted, Florentines' relationship to the state was both adversarial and participatory, and this duality had significant consequences for macro-political developments. And here we return to the question of why the modern state stalled in Italy, a question that comparative historical sociology has so far failed to answer satisfactorily.

The problem is not exactly the old one that has long handicapped classic state modernization theory (Moore 1966; Anderson 1974; Tilly et al. 1975; Evans, Rueschemeyer, and Skocpol 1985; Levi 1988). That theory's models were based rather simplistically on war-making, class conflict, or the interests of state actors, and they have been supplanted with models that stress, for example, political institutional conditions as critical factors in state-building trajectories (Downing 1991; Ertman 1997). Particularly with respect to Italian state development, recent sociological scholarship has stressed coalitions among key groups and a balance of the essential resources they controlled as critical determinants of state outcomes. Thus Tilly (1992) argues that a balance between coercive capacity and capital accumulation was important for state-making. The Italians, he argues, concentrated on the latter to the relative exclusion of the former, resulting in imperfectly implemented, centralized states that were ultimately unwilling to prosecute wars (1992:65, 77-78). However, Tilly's model falls somewhat short of the mark: most of the Italian city-states did wage wars, both on behalf of commercial enterprise and in pursuit of military security, with substantial resources at their disposal, for considerable lengths of time, at significant levels of financial sacrifice. More importantly, rather than shirking their responsibilities, a relatively small number of Florentine citizens who were simultaneously merchants and politicians (as well as fathers, ambassadors, neighbors, and so on; see Padgett and McLean 2002) repeatedly carried a disproportionately large share of the office-holding and fiscal burden of the city. Political savvy was not lacking, but it was attached to the role of cives (citizen) rather than to a distinct group in society.

Hendrik Spruyt (1994) has argued, effectively contra Tilly, that we should not be satisfied with viewing the sovereign state as a "just-right" balance of requisite inputs. Why did the city-state form perish, while the territorial sovereign 
state flourished? Spruyt's principal explanation is that the early and ongoing presence of nobles within the Italian city-states resulted in an unstable state pact between commercial patricians and the martial nobility. The city-states faced a recurrent threat of factionalism generated by antagonism between its leading classes (1994:130, 137ff.), and so the legitimacy of the communal government's claim to speak on behalf of all citizens was continually challenged (1994:149). By contrast, sovereign leaders were more effective in curtailing free riding within the polity, more capable of making credible commitments, and more likely to recognize each other than to recognize actors adopting alternative forms of governance $(1994: 155,176)$, thus reinforcing their numerical dominance in the European political system. However, Spruyt affords scant analytical attention to how the various groups in city-states actually interacted. Nor does he consider that members of the Florentine ruling class had a greater diversity of interests and identities than a simple rendering of the map of class interests would lead us to believe.

One of the most insightful comparative-historical treatments of the Italian city-states to date in sociology appears in Richard Lachmann's Capitalists in Spite of Themselves (2000). Lachmann attends to the outcomes of actual conflicts, rather than simply specifying a static model of the logical consequences of finding a particular array of elite groups in the same space. Throughout Europe, "elite conflict propelled forward each era of transformation" in the development of the early modern state and the concomitant development of, in Weber's words, "economically oriented capitalism" (2000:9, 45). "Opportunities for agency" from below are a function of the structure of elite relations (2000:11). Thus, factional divisions among Florentine magnates in the late 1200s provided urban patricians (the popolani) with the opportunity to take control of the state (2000:57). In 1343, a split within the popolani, combined with economic crises, enabled an alliance of magnates and lower guildsmen to challenge the regime. Conversely, a challenge from below in the Ciompi rebellion of 1378-1382 resulted in a reconsolidated alliance of popolani with minor guildsmen to exclude the working class sottoposti from political participation (2000:77; Padgett and Ansell 1993). This alliance produced dramatic growth in patron-client attachments among elites, and to rank-and-file Florentines, thereby defusing a good deal of the city's class politics (Najemy 1982; Kent 1978). However, Lachmann argues, it also limited elites' ability to forge innovative political and diplomatic policy. In a recent extension of this argument, Tarrow (2004) asserts that patronage-based factionalism produced a landscape of contentious politics and political instability that severely inhibited the Florentine state from building a strong military that was the hallmark of early modern European state formation. From 1434 on, the Medici successfully deflected challenges to their supremacy through quasi-monopoly control of communal offices and access to capital, and yet Medici measures to control the political and fiscal process often barely achieved sufficient popular support (Rubinstein 
1997). Clientelistic politics hampered the development of an autonomous state (and a more revolutionary economy). ${ }^{27}$ This can only be properly understood, Lachmann periodically acknowledges $(2000: 78,83)$, by seeing the ways personal loyalties were played out, not only at the level of groups, the boundaries of which were constantly being redrawn, but also at the level of interpersonal interaction. Such interaction was not only contentious (Rubinstein 1997; Tarrow 2004), but frequently cooperative. Florentines found ways to cooperate across group and status boundaries in ways that hampered the emergence of an autonomous state.

Still, Lachmann overstates the clarity of distinctions between groups, and understates certain groups' commitments to the regime as a whole and its perpetuation. Not all political choices were as self-interested as he suggests. He underestimates the enormous involvement of the "oligarchic" families in the commercial economy, overstates the distinction between popolani and new men, and implicitly disregards the fact that some of the richest Florentine citizens were at least mild supporters of state administrative innovations that might have jeopardized their immediate interests.

How, then, did interpersonal politicking constrain state action and shape the spirit and understanding of governance? Problems with the emergence of a strong Florentine state brewed up from a shifting array of interactions among individuals constituted not by simple group identities, but by multiple affiliations and roles, any number of which could be activated to achieve personal objectives. Among these identities were the roles of father and neighbor, for example, that suggested private interests at some odds with the state, and that of office-holder, which suggested some congruence between individual and state interests. Only by studying interactions can we see how and when these identities were invoked, and with what consequences for the development of the state. This is because state institutions and rules of thumb for interpersonal interaction developed side by side.

To conclude, administrative change in Florence was accomplished within the constraints of a contest, not between state actors and civil society, but between citizens in their role as custodians of the state, and the same citizens in their role as subjects to the state. Certainly the modest separation of the state from the citizenry allowed the onerous tax burden to be accepted as legitimate to a remarkable degree, recurrent grumblings of the populace aside. The implication of the Tilly, Spruyt, and Lachmann story-line, that Florentine elites were sim-

27 On the economic side-which concerns Lachmann more deeply — the paternalistic treatment of lower guildsmen successfully defused guild-based corporatist politics, but simultaneously shackled the political cum economic elite to traditional economic arrangements and commercial ventures. Specifically, it meant sticking with the decreasingly profitable production of luxury cloth goods in lieu of moving to low-cost mass production, a move blocked by guild regulations and restrictions. Once political stability was more or less achieved, the commercial classes of the Italian city-states began to imitate the social strategies of those groups they had successfully defeated in the past, thus becoming, in Weber's words, a politically oriented capitalist class. 
ply unwilling to burden themselves with a more costly and powerful state, does not hold up. And yet the embeddedness of the state in its private citizenry obviously affected the extent to which it could develop in an autonomous manner. Administrative developments in the fiscal state-in fact, a succession of alternately modern and traditional strategies for accumulating resources necessary for the protection and growth of the territorial state-constantly and repeatedly created and reinforced personalistic, honor-driven relations. These relations ultimately jeopardized the state's strength and autonomy in a way very different from that suggested by a shorthand class analysis. However much Florentine statemakers desired reform, they found it impossible or inconceivable to establish a fiscal regime that would decouple taxation from political participation. In fact, expansion of the privilege of political participation was repeatedly used, especially by the Medici, to quell potential unrest (D. Kent 1987; Najemy 1982; 1991). Accordingly, Florentine leaders countenanced and even encouraged widespread personalistic patronage. Just as incipient state-building in the form of the catasto was a largely unintended consequence of Florentine collective fiscal decision-making under crisis, so too the strengthening of informal, politically active networks that undercut state autonomy was an unintended consequence of the state-building process itself. And this was so, to a significant extent, because of the constraints imposed by the institutional demands of republican government.

\section{REFERENCES}

\section{Archival Sources}

All in Archivio di Stato di Firenze [A.S.F.]:

Carte del Bene, 49

Carte Strozziane, III'e serie

Catasto

Conventi Soppressi, 78

Mediceo avanti il Principato

\section{Published Sources}

Alberti, Leon Battista. 1969. I Libri della famiglia. A cura di Ruggiero Romano e Alberto Tenenti. Torino: Giulio Einaudi editore.

Anderson, Perry. 1974. Lineages of the Absolutist State. London: New Left Books; Verso.

Branca, Vittore, ed. 1986. Mercanti scrittori: Ricordi nella Firenze tra Medioevo e Rinascimento [Paolo da Certaldo, Giovanni Morelli, Bonaccorso Pitti e Domenico Lenzi, Donato Velluti, Goro Dati, Francesco Datini, Lapo Niccolini, e Bernardo Machiavelli]. Milano: Rusconi.

Chittolini, Giorgio. 1996. The "Private," the "Public," the State. In, Julius Kirshner, ed., The Origins of the State in Italy, 1300-1600. Chicago: University of Chicago Press, 34-61.

Cohn, Samuel K., Jr. 1999. Creating the Florentine State: Peasants and Rebellion, 1348-1434. Cambridge: Cambridge University Press. 
Connell, William J. 1994. Changing Patterns of Medicean Patronage: The Florentine Dominion during the Fifteenth Century. In, Lorenzo il Magnifico e il suo mondo, a cura di Gian Carlo Garfagnini (ed.). Firenze: Olschki, 87-107.

-2000. La città dei crucci: Fazioni e clientele in uno stato repubblicano del '400. Firenze: Nuova Toscana Editrice.

Connell, William J. and Andrea Zorzi. 2000. Florentine Tuscany: Structures and Practices of Power. Cambridge: Cambridge University Press.

Conti, Elio. 1984. L'imposta diretta a Firenze nel Quattrocento (1427-1494). Roma: Istituto storico italiano per il medio evo, Palazzo Borromini.

Davis, Natalie Zemon. 2000. The Gift in Sixteenth-Century France. Madison: University of Wisconsin Press.

De Roover, Raymond. 1966. The Rise and Decline of the Medici Bank, 1397-1494. New York: W. W. Norton \& Company, Inc.

Dini, Bruno. 2001. Le forme e le tecniche del prestito nel tardo Medioevo. In Manifattura, commercio e banca nella Firenze medievale. Firenze: Nardini Editore.

Downing, Brian. 1991. The Military Revolution and Political Change: Origins of Democracy and Autocracy in Early Modern Europe. Princeton: Princeton University Press.

Eisenstadt, S. N. and Louis Roniger. 1984. Patrons, Clients and Friends: Interpersonal Relations and the Structure of Trust in Society. Cambridge: Cambridge University Press.

Elias, Norbert. 1978. The Civilizing Process. Edmund Jephcott, trans. Oxford: Blackwell.

Eliasoph, Nina. 1990. Political Culture and the Presentation of a Political "Self." Theory and Society 19:465-94.

Emigh, Rebecca Jean. 1998. The Mystery of the Missing Middle-Tenants: The "Negative" Case of Fixed-Term Leasing and Agricultural Investment in Fifteenth-Century Tuscany. Theory and Society 27:351-75.

- 2003. Economic Interests and Sectoral Relations: The Undevelopment of Capitalism in Fifteenth-Century Tuscany. American Journal of Sociology 108, 5:1075-113.

Epstein, S. R. 2000a. Freedom and Growth: The Rise of States and Markets in Europe, 1300-1750. London and New York: Routledge.

_ 2000b. Market Structures. In, William J. Connell and Andrea Zorzi, eds., Florentine Tuscany: Structures and Practices of Power. Cambridge: Cambridge University Press, 90-121.

Ertman, Thomas. 1997. Birth of the Leviathan: Building States and Regimes in Medieval and Early Modern Europe. Cambridge: Cambridge University Press.

Evans, Peter, Dietrich Rueschemeyer, and Theda Skocpol, eds. 1985. Bringing the State Back In. Cambridge: Cambridge University Press.

Fabbri, Lorenzo. 1991. Alleanza matrimoniale e patriziato nella Firenze del '400: Studio sulla famiglia Strozzi. Firenze: Leo S. Olschki.

Fasano Guarini, Elena. 1996. Center and Periphery. In, Julius Kirshner, ed., The Origins of the State in Italy, 1300-1600. Chicago: University of Chicago Press, 74-96.

Fubini, Riccardo. 1994. Italia Quattrocentesca: Politica e diplomazia nell'età di Lorenzo il Magnifico. Milano: FrancoAngeli.

Goldthwaite, Richard A. 1985. Local Banking in Renaissance Florence. Journal of European Economic History 14, 1:5-55.

. 1987. The Medici Bank and the World of Florentine Capitalism. Past and Present $114: 3-31$.

Herlihy, David. 1991. The Rulers of Florence, 1282-1530. In, Anthony Molho, Kurt Raaflaub, and Julia Emlen, eds., City States in Classical Antiquity and Medieval Italy. Ann Arbor: University of Michigan Press, 197-221. 
Herlihy, David and Christiane Klapisch-Zuber. 1985. Tuscans and Their Families: A Study of the Florentine Catasto of 1427. New Haven and London: Yale University Press.

Ikegami, Eiko. 1995. The Taming of the Samurai: Honorific Individualism and the Making of Modern Japan. Cambridge, Mass.: Harvard University Press.

Jepperson, Ronald L. 1991. Institutions, Institutional Effects, and Institutionalism. In, Walter W. Powell and Paul J. Dimaggio, eds., The New Institutionalism in Organizational Analysis. Chicago: University of Chicago Press, 143-63.

Kent, Dale. 1978. The Rise of the Medici: Faction in Florence, 1426-1434. Oxford: Oxford University Press.

1987. The Dynamic of Power in Cosimo de' Medici's Florence. In, F. W. Kent and Patricia Simons, eds., Patronage, Art and Society in Renaissance Italy. Canberra: Humanities Research Centre; Oxford: Clarendon Press, 63-77.

. 2000. Cosimo de'Medici and the Florentine Renaissance. New Haven and London: Yale University Press.

Kent, Francis William. 1991. Bartolommeo Cederni and His Friends: Letters to an Obscure Florentine. Introductory essay by F. W. Kent, and texts edited by Gino Corti with F. W. Kent. Florence: Leo S. Olschki, Istituto Nazionale di Studi sul Rinascimento.

Lachmann, Richard. 2000. Capitalists in Spite of Themselves: Elite Conflict and Economic Transitions in Early Modern Europe. New York and Oxford: Oxford University Press.

Levi, Margaret. 1988. Of Rule and Revenue. Berkeley: University of California Press.

McLean, Paul D. 1996. "Patronage and Political Culture: Frames, Networks and Strategies of Self-Presentation in Renaissance Florence.” Ph.D. dissertation, University of Chicago.

- 1998. A Frame Analysis of Favor Seeking in the Renaissance: Agency, Networks, and Political Culture. American Journal of Sociology 104, 1:51-91.

McLean, Paul D. and John F. Padgett. 2004. Obligation, Risk, and Opportunity in the Renaissance Economy: Beyond Social Embeddedness to Network Co-Constitution. In, Frank Dobbin, ed., The Sociology of the Economy. New York: Russell Sage, 193-227.

Melis, Federigo. 1991. L'azienda nel medioevo. Firenze: Le Monnier.

Molho, Anthony. 1971. Florentine Public Finances in the Early Renaissance, 14001433. Cambridge, Mass.: Harvard University Press.

. 1979. Cosimo de' Medici: Pater Patriae or Padrino? Stanford Italian Review 1:5-33.

1987. L'amministrazione del debito pubblico a Firenze nel quindicesimo secolo. In I ceti dirigenti nella Toscana del Quattrocento. Comitati di studi sulla storia dei ceti dirigenti in Toscana: Atti del V e VI Convegno. Firenze: Francesco Papafava editore, 191-208.

- 1994. Marriage Alliance in Late Medieval Florence. Cambridge, Mass.: Harvard University Press.

1996. The State and Public Finance: A Hypothesis Based on the History of Late Medieval Florence. In, Julius Kirshner, ed., The Origins of the State in Italy, 13001600. Chicago: University of Chicago Press, 97-135.

Moore, Barrington, Jr. 1966. Social Origins of Dictatorship and Democracy. Boston: Beacon Press.

Najemy, John M. 1982. Corporatism and Consensus in Florentine Electoral Politics, 1280-1400. Chapel Hill: The University of North Carolina Press.

1991. The Dialogue of Power in Florentine Politics. In, Anthony Molho, Kurt Raaflaub, and Julia Emlen, eds., City States in Classical Antiquity and Medieval Italy. Ann Arbor: University of Michigan Press, 269-88. 
Padgett, John F. 2001. Organizational Genesis, Identity, and Control: The Transformation of Banking in Renaissance Florence. In, James E. Rauch and Alessandra Casella, eds., Networks and Markets. New York: Russell Sage Foundation, 211-57.

Padgett, John F. and Christopher K. Ansell. 1993. Robust Action and the Rise of the Medici, 1400-1434. American Journal of Sociology 98, 6:1259-319.

Padgett, John F. and Paul D. McLean. 2002. Economic and Social Exchange in Renaissance Florence. Santa Fe: Santa Fe Institute, Working Paper 02-07-032.

Petralia, Giuseppe. 2000. Fiscality, Politics, and Dominion in Florentine Tuscany at the End of the Middle Ages. In, William J. Connell and Andrea Zorzi, eds., Florentine Tuscany: Structures and Practices of Power. Cambridge: Cambridge University Press, 65-89.

Reddy, William M. 1997. The Invisible Code: Honor and Sentiment in Postrevolutionary France, 1814-1848. Berkeley: University of California Press.

Rubinstein, Nicolai. 1997 [1966]. The Government of Florence Under the Medici (1434 to 1494). 2d ed. Oxford: Clarendon Press.

Somers, Margaret R. 1995. What's Political or Cultural about Political Culture and the Public Sphere? Toward an Historical Sociology of Concept Formation. Sociological Theory 13, 2:113-44.

Spruyt, Hendrik. 1994. The Sovereign State and Its Competitors. Princeton: Princeton University Press.

Tarrow, Sidney. 2004. "From Comparative Historical Analysis to "Local Theory": An Expansion of Charles Tilly's Model of the Renaissance City-States." Unpublished MS.

Tilly, Charles, ed. 1975. The Formation of National States in Western Europe. Princeton, N.J.: Princeton University Press.

1992. Coercion, Capital and European States, 990-1992. Cambridge, Mass. and Oxford, U.K.: Blackwell.

Trexler, Richard C. 1980. Public Life in Renaissance Florence. New York: Academic Press; Ithaca, N.Y. and London: Cornell University Press.

Weissman, Ronald F. E. 1982. Ritual Brotherhood in Renaissance Florence. New York: Academic Press.

. 1989. The Importance of Being Ambiguous: Social Relations, Individualism, and Identity in Renaissance Florence. In, Susan Zimmerman and Ronald F. E. Weissman, eds., Urban Life in the Renaissance. Newark: University of Delaware Press, 269-80. 